\title{
Air-Sea Interaction over the Eastern Pacific Warm Pool: Gap Winds, Thermocline Dome, and Atmospheric Convection*
}

\author{
SHANG-PING XIE \\ International Pacific Research Center and Department of Meteorology, University of Hawaii at Manoa, Honolulu, Hawaii \\ HAIMING XU \\ International Pacific Research Center, University of Hawaii at Manoa, Honolulu, Hawaii \\ WILLIAM S. KESSLER \\ NOAA/Pacific Marine Environmental Laboratory, Seattle, Washington \\ MASAMI NONAKA \\ Frontier Research Center for Global Change, Yokohama, Japan
}

(Manuscript received 2 April 2004, in final form 5 July 2004)

\begin{abstract}
High-resolution satellite observations are used to investigate air-sea interaction over the eastern Pacific warm pool. In winter, strong wind jets develop over the Gulfs of Tehuantepec, Papagayo, and Panama, accelerated by the pressure gradients between the Atlantic and Pacific across narrow passes of Central American cordillera. Patches of cold sea surface temperatures (SSTs) and high chlorophyll develop under these wind jets as a result of increased turbulent heat flux from the ocean and enhanced mixing across the base of the ocean mixed layer. Despite a large decrease in SST (exceeding $3^{\circ} \mathrm{C}$ in seasonal means), the cold patches associated with the Tehuantepec and Papagayo jets do not have an obvious effect on local atmospheric convection in winter since the intertropical convergence zone (ITCZ) is located farther south. The cold patch of the Panama jet to the south, on the other hand, cuts through the winter ITCZ and breaks it into two parts.

A pronounced thermocline dome develops west of the Gulf of Papagayo, with the $20^{\circ} \mathrm{C}$ isotherm only $30 \mathrm{~m}$ deep throughout the year. In summer when the Panama jet disappears and the other two wind jets weaken, SST is $0.5^{\circ} \mathrm{C}$ lower over this Costa Rica Dome than the background. This cold spot reduces local precipitation by half, punching a hole of $500 \mathrm{~km}$ in diameter in the summer ITCZ. The dome underlies a patch of open-ocean high chlorophyll. This thermocline dome is an ocean dynamic response to the positive wind curls south of the Papagayo jet, which is optimally oriented to excite ocean Rossby waves that remotely affect the ocean to the west. The meridionally oriented Tehuantepec and Panama jets, by contrast, only influence the local thermocline depth with few remote effects on SST and the atmosphere. The orographical-triggered air-sea interaction described here is a good benchmark for testing high-resolution climate models now under development.
\end{abstract}

\section{Introduction}

The ocean-atmosphere system over the eastern tropical Pacific displays large north-south asymmetry with respect to the equator. While surface water on and south

\footnotetext{
* International Pacific Research Contribution Number 288, School of Ocean and Earth Science and Technology Contribution Number 6453, and Pacific Marine Environmental Laboratory Contribution Number 2677.
}

Corresponding author address: Shang-Ping Xie, International Pacific Research Center, SOEST, University of Hawaii at Manoa, Honolulu, HI 96822.

E-mail: xie@hawaii.edu of the equator remains below $26^{\circ} \mathrm{C}$ year-round, sea surface temperature (SST) to the north off the coast of Central America is mostly above $27^{\circ} \mathrm{C}$, a region we hereafter refer to as the eastern Pacific warm pool. The warm pool is bounded on the south by a sharp SST front slightly north of the equator that separates the equatorial cold tongue from the warm water to the north. Deep atmospheric convection with heavy precipitation is generally confined to the north of this equatorial front, with dry conditions prevailing on and south of the equator. This region of strong atmospheric convection is called the intertropical convergence zone (ITCZ), onto which the southeast and northeast trades converge. This climatic asymmetry between north and south of the equator results from air-sea interaction triggered by latitudinal 

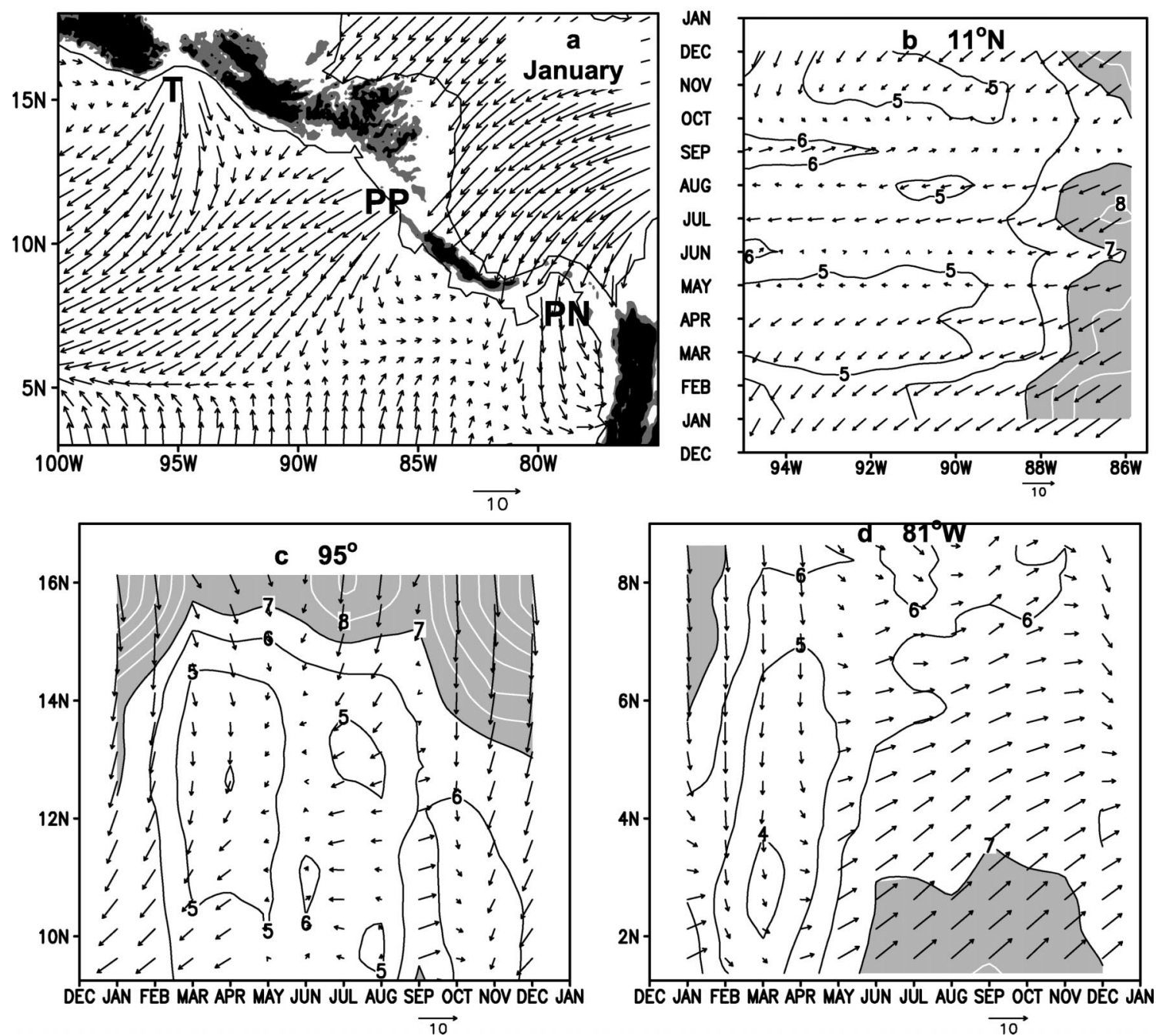

FIG. 1. (a) Wind jets over the Gulfs of Tehuantepec (T), Papagayo (PP), and Panama (PN) in the QuikSCAT surface wind velocity (m $\mathrm{s}^{-1}$ ) climatology for Jan. (b) Longitude-time section of wind velocity $(u, v)$ and scalar speed (contours; shade $\left.>7 \mathrm{~m} \mathrm{~s}^{-1}\right)$ at $11^{\circ} \mathrm{N}($ Papagayo gap). Latitude-time sections of wind velocity and scalar speed (contours; shade $>7 \mathrm{~m} \mathrm{~s}^{-1}$ ) (c) at $95^{\circ} \mathrm{W}$ (Tehuantepec gap), and (d) at $81^{\circ} \mathrm{W}$ (Panama gap). In (a) the light and dark shades denote topography greater than 500 and $1000 \mathrm{~m}$, respectively.

asymmetries in continental geometry (see Xie 2004a for a recent review). The eastern Pacific warm pool is climatically important, supporting one of the major convection centers of the global atmosphere (Mitchell and Wallace 1992; Wang and Enfield 2003). Hurricanes that originate there travel northwestward, some reaching Hawaii, $6000 \mathrm{~km}$ away.

The continents on the eastern boundary of the Pacific are also highly asymmetrical. The steep and high Andes separate the Pacific lower troposphere from that of the South American continent and the Atlantic while a mountain range runs through the narrow Central American land bridge as an extension of the Sierra Madre Occidental from North America. This Central American cordillera is about $1 \mathrm{~km}$ high on average, blocking lowlevel airflow from the Caribbean Sea. Three major gaps penetrate this mountain range: at the isthmus of Te- huantepec, over Lake Nicaragua, and at Panama (Fig. 1a). In boreal winter, sea level pressure is often higher over the Caribbean and Gulf of Mexico than on the Pacific side, forcing strong wind jets through these gaps and over the eastern Pacific warm pool. On synoptic time scales, these gap wind events may occur in sequence or independently (Chelton et al. 2000). There have been many studies on the wind jet over the Gulf of Tehuantepec during the boreal winter. Steenburgh et al.'s (1998) model simulation shows that during these high-wind events, strong pressure gradients between the Atlantic and Pacific accelerate the winds to high speeds along the narrow mountain passes. After leaving the coast, air trajectories tend to follow anticyclonic arcs, which Clarke (1988) suggests are inertial flow nearly free of pressure gradient force. In Steenburgh et al.'s (1998) model, the Atlantic air mass, with cold temper- 
atures and high sea level pressure, penetrates a few hundred kilometers over the Gulf of Tehuantepec, and these pressure anomalies significantly modify the trajectories and cause them to deviate from the inertial circle. A cloud arc sometimes forms along the cold front and advances offshore with the cold surge over the Gulf of Tehuantepec (Schultz et al. 1997), perhaps due to the upward motion associated with gravity currents.

Figure 1a shows the January surface wind velocity averaged for 2000-03. The Tehuantepec jet is clearly visible in this climatological wind map, and so are two other wind jets to the south (the Papagayo and Panama jets hereafter). Wind speeds are typically $10 \mathrm{~m} \mathrm{~s}^{-1}$ in these climatological wind jets while winds lee of the mountain range are one order of magnitude weaker. The wind jets extend a few hundred kilometers offshore, with the Tehuantepec and Papagayo jets eventually merging into the Pacific northeast trades. The Tehuantepec and Panama jets are oriented roughly in the northsouth direction while the Papagayo jet takes a nearly zonal orientation. As will become clear, this difference in the jet orientation results in distinct subsurface ocean response to these wind jets.

These wind jets are strongest during boreal winter, and exert a strong influence on the surface ocean, as readily seen from satellite infrared observations (Clarke 1988; Legeckis 1988; Barton et al. 1993). It is quite common for SST near these wind jets to drop by several degrees during a strong wind surge event, due to intensified surface turbulent heat flux and entrainment. Over the eastern Pacific warm pool east of $95^{\circ} \mathrm{W}$, the thermocline is less than $50 \mathrm{~m}$ deep. Strong wind stirring together with surface heat flux cooling is thus very effective in entraining cold thermocline water into the surface mixed layer. Besides the SST decreases, enhanced entrainment also gives rise to increased biological activity beneath these wind jets in winter (Fiedler 2002 and references therein).

Strong wind curl associated with the wind jets create rich structures in the thermocline over the eastern Pacific warm pool, which have been attributed to several dynamical mechanisms (Hofmann et al. 1981; McCreary et al. 1989; Umatani and Yamagata 1991; Kessler 2002). In particular, the Costa Rica Dome in the thermocline is a permanent cyclonic eddy, which is centered at $9^{\circ} \mathrm{N}$, $90^{\circ} \mathrm{W}$ and expands seasonally to the west in boreal summer. In the Costa Rica Dome, the $20^{\circ} \mathrm{C}$ isotherm is very close to the sea surface, only $30 \mathrm{~m}$ deep on long-term mean. The upwelling and mixing in this thermocline dome make it rich in nutrients, supporting a rich fishery and attracting marine mammals such as blue whales and common dolphins (Fiedler 2002). Kessler (2002) estimates a $3.5 \mathrm{~Sv}\left(1 \mathrm{~Sv} \equiv 10^{6} \mathrm{~m}^{3} \mathrm{~s}^{-1}\right)$ mean upwelling in the Costa Rica Dome and suggests that it is an important element of the Pacific intermediate-water circulation. McCreary et al. (2002) argue based on ocean model experiments that this upwelling drives an eastward subsurface jet north of the equator-the Tsuchiya jet-that is associated with a strong potential vorticity front in the thermocline. See Kessler (2004, hereafter KES) for a recent review of eastern Pacific Ocean circulation.

The present study investigates the climatic effects of these Central American gap winds. These winds imprint on winter SST as cold patches over the otherwise warm water from $5^{\circ}-15^{\circ} \mathrm{N}$. Kessler (2002) further notes an "isolated cool spot near $9^{\circ} \mathrm{N}, 90^{\circ} \mathrm{W}$ " (e.g., Fig. 4) in annual-mean SST that "marks the surface expression of the Costa Rica Dome." It is unclear, however, whether this cold spot results exclusively from the gap wind effect in winter or if such an SST expression of the Dome is seen in other seasons as well. While there are several studies of the gap wind effect on the ocean, to our knowledge, the feedback of gap wind-induced SST changes on the atmosphere has not been discussed in the literature. Given high background SSTs over the eastern Pacific warm pool that exceed the convective threshold $\left(\sim 27^{\circ} \mathrm{C}\right)$, cold spots induced by gap winds would conceivably suppress local convection. The coarse spatial resolution of rainfall estimates based on spaceborne infrared remote sensing makes it difficult to detect such signatures. For example, the widely used Climate Prediction Center (CPC) Merged Analysis of Precipitation (CMAP) product (Xie and Arkin 1996) has a resolution of $2.5^{\circ}$, the same scale as the cold spots in the eastern Pacific warm pool.

The present study takes advantage of recent observations by spaceborne microwave instruments to examine the gap wind-induced air-sea interaction over the eastern Pacific warm pool, including the ocean-toatmospheric feedback. These microwave observations allow a more direct inference of rainfall and at higher resolution than infrared sensing, and measure SST nearly free of clouds. Unlike many previous studies on synoptic wind events, our focus is on monthly and seasonal time scales. Specific questions we would like to address are: How do these winds force variations in SST and the subsurface ocean? Does the shallow thermocline of the Costa Rica Dome have a significant effect on SST? Do these SST signatures of gap winds influence atmospheric convection and does this influence vary with season? The first question has been considered to some degree in previous studies, but new satellite observations of the ocean and atmosphere now allow us to synthesize various aspects and gain a physically consistent picture of this air-sea interaction. Our analysis shows that in boreal summer when the gap winds are weak, the shallow thermocline of the Costa Rica Dome maintains a cold spot, which in turn suppresses local atmospheric convection. Somewhat surprisingly, the ocean-to-atmospheric feedback is less clear in boreal winter despite strong gap winds at that time.

The rest of the paper is organized as follows. Section 2 describes the datasets. Section 3 presents the results, and section 4 is a summary. 


\section{Data}

This study analyzes a suite of satellite observations of SST, sea surface height (SSH), sea surface wind, and chlorophyll by several different sensors on different platforms. These new satellite observations offer a view of the oceans and the overlying atmosphere in detail never possible before, stimulating a recent flurry of airsea interaction studies (see Xie 2004b for a recent review, and references therein).

The Tropical Rainfall Measuring Mission (TRMM) satellite's Microwave Imager (TMI) can measure SST nearly through clouds over the global Tropics within $38^{\circ} \mathrm{N} / \mathrm{S}$. This microwave remote sensing substantially improves the sampling of SST over cloudy regions like the eastern Pacific warm pool. TMI also measures rain rate. We use a monthly TMI product available from January 1998 to December 2003 on a $0.25^{\circ}$ grid (Wentz et al. 2000). There are considerable uncertainties in quantitative rainfall estimates using satellite observations. Here we limit ourselves to a qualitative discussion of spatial variations in rainfall in response to gap winds and solar seasonal cycle. We will compare this TMI product with other independent measurements of rainfall on board TRMM. On a $0.5^{\circ}$ grid, the $3 \mathrm{~A} 25 \mathrm{G} 2$ product is based on the precipitation radar (PR) observations. The PR makes the best estimate of precipitation but its narrow swath introduces larger sampling errors for climatological averages. On a $1^{\circ}$ grid, the $3 \mathrm{~B} 43$ product combines infrared observations by TRMM and geostationary satellites and rain gauges, which is an indirect inference of rainfall over the ocean but enjoys good sampling and coverage. The PR and infrared products provide rainfall over both land and ocean while the TMI product is limited to the open ocean.

The microwave scatterometer on the National Aeronautics and Space Administration's Quick Scatterometer (QuikSCAT) satellite measures daily surface wind velocity over the world ocean (Liu et al. 2000). QuikSCAT observations have revealed rich wind structures on short spatial scales around the world (Chelton et al. 2004). We use a monthly product for wind velocity for August 1999-December 2003 on a $0.25^{\circ}$ grid. Pseudo-wind stress is constructed from the QuikSCAT daily neutral wind velocity product.

The Sea-viewing Wide Field-of-view Sensor (SeaWiFS) satellite measures ocean color and chlorophyll concentration from October 1997 to November 2003 , which are often a good indicator of ocean upwelling. We use monthly averages on a $0.25^{\circ}$ grid.

The upper-thermocline depth, when shallow, can have important effects on SST. We use the $20^{\circ} \mathrm{C}$ isotherm depth based on a monthly ocean temperature climatology on a $1^{\circ} \times 1^{\circ}$ grid, which is derived from historical expendable bathythermograph (XBT) observations. Most temperature profiles were during 1979 through 1992, and a smaller number of profiles after that date are also used in constructing the climatology. This XBT climatology compares quite well with independent SST observations. See Kessler (2002) for a detailed description of this dataset.

Altimeters on the European Remote Sensing (ERS) and TOPEX/Poseidon (T/P) satellites measure SSH deviations from its long-term mean at their nadir. There is a trade-off between spatial and temporal resolution: $\mathrm{T} / \mathrm{P}$ has a 10-day repeat orbit with a wide zonal spacing between ground tracks, while ERS has a 35-day repeat orbit with a small track spacing. We use a merged SSH dataset that takes advantage of both T/P's high temporal and ERS's high spatial resolutions (Ducet et al. 2000), available from October 1992 to July 2001 on a $0.25^{\circ}$ grid. We use this merged SSH dataset to infer the seasonal cycle in thermocline depth.

Monthly climatologies are constructed for TRMM SST and rainfall, QuikSCAT surface wind velocity/ stress, merged ERS-T/P SSH, and SeaWiFS chlorophyll for periods these observations are available. The discussion that follows is limited to these multiyear climatologies, while submonthly and interannual variability is beyond the scope of this study. See Wang and Enfield (2003) and Chiang et al. (2000) for recent studies of interannual variability over the region and its effect on the Atlantic. In general, signals to be discussed here are well above measurements errors. We refer to relevant references earlier for satellite-data error analysis. For our analysis, we use several independent measurements, which turn out to yield mutually corroborating and physically consistent results. Such physical consistency gives us confidence in the results.

\section{Results}

\section{a. Wind jets}

In the paper, we discuss the Central American wind jets based on the monthly mean climatology, although there is considerable variability on the synoptic time scales (Chelton et al. 2000). Our use of monthly climatology is based on the linear assumption that the lowfrequency forcing drives the low-frequency ocean circulation (KES). During winter, all three jets are well developed on the Pacific side of the major mountain passes (Fig. 1). By contrast, winds are generally low in the lee of the Central American mountains with elevations above $1 \mathrm{~km}$.

While previous studies have focused principally on the winter jets, Fig. 1 shows the full seasonal cycle of these wind jets along the longitude or latitude where their axes leave the coast. The Tehuantepec jet is strongest during October-February, but a weaker northerly wind jet remains visible in summer over the Gulf of Tehuantepec. The Papagayo and Panama jets display slightly different seasonality, peaking in DecemberApril. While the Panama jet ceases to occur after April, the Tehuantepec and Papagayo jets persist in other months with reduced speeds. The Papagayo jet disap- 


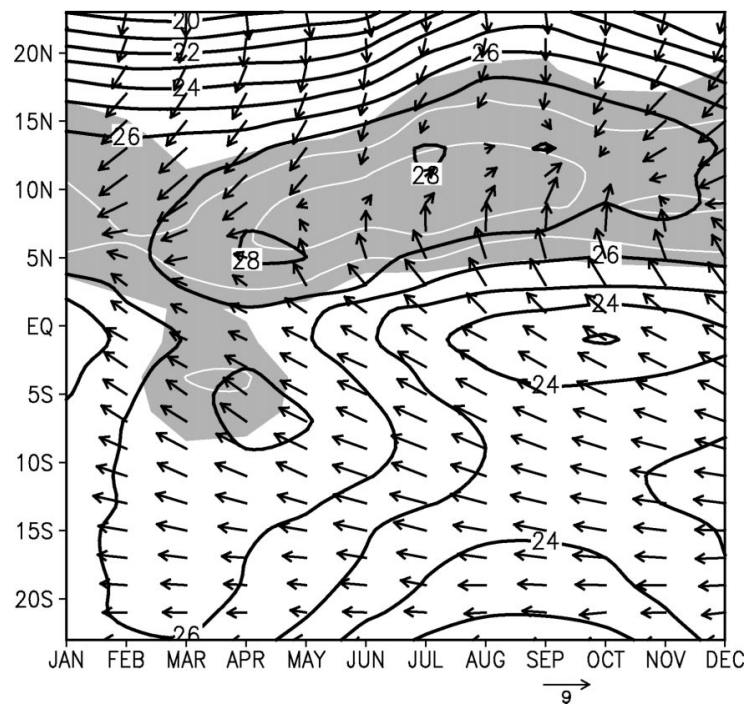

FIG. 2. Time-latitude section of climatological SST (black contours in ${ }^{\circ} \mathrm{C}$ ); surface wind vectors ( $\mathrm{m} \mathrm{s}^{-1}$ ), based on COADS; and CMAP precipitation (white contours at $5 \mathrm{~mm} \mathrm{day}^{-1}$ intervals; shade $>2.5$ $\mathrm{mm}$ day $^{-1}$ ), all zonally averaged in $120^{\circ}-115^{\circ} \mathrm{W}$.

pears altogether only in September, the time the Tehuantepec jet is also at its minimum. Both the Tehuantepec and Papagayo jets show a secondary peak during July-August, which may be associated with the midsummer drought over southern Mexico and Central America (Fig. 8 of Magana et al. 1999).

In the following, we will display several figures in a common format for easy comparison among various observations. Each figure has three parts for annual, January-April, and July-October means, respectively. January-April are months when the ITCZ is close to the equator (Fig. 2) and all three wind jets are reasonably strong. The ITCZ moves to its northernmost latitudes during July-October. Figure 2 includes surface wind vectors based on the Comprehensive Ocean-Atmosphere Dataset (COADS).

Figure 3 shows the wind stress vectors and Ekman pumping velocity, $w_{e}=\operatorname{curl}(\boldsymbol{\tau} / f \rho)$, where $\boldsymbol{\tau}$ is the wind stress vector, $f$ the Coriolis parameter and $\rho$ the water density. While winds are easterly to northeasterly yearround over the Caribbean, large seasonal variations in winds are seen over the eastern Pacific warm pool. There, the northeast trades prevail, converging onto the ITCZ at $5^{\circ} \mathrm{N}$ in winter, but vector winds are weak north of $10^{\circ} \mathrm{N}$ under the ITCZ in summer. The seasonal shifts in winds are particularly large between $5^{\circ}-10^{\circ} \mathrm{N}$, reversing from northeasterly in winter to southwesterly in summer as the ITCZ migrates with the sun. (The zonal band of upward Ekman pumping is generally collocated with the ITCZ that maintains positive vorticity of the surface flow.) As shown in Fig. 3, the Tehuantepec and Papagayo jets remain clearly visible in summer, although considerably weaker in both speed and offshore extent than in winter. In summer, there is no evidence for climatological gap winds off Panama; instead, winds converge onto the warm continent from the ocean on both sides.

\section{b. Effect on thermocline depth}

A dipole wind-curl pattern is associated with each of the gap wind jets (Fig. 3). While the speed of the Papagayo jet decreases by half from winter to summer, surprisingly, the Ekman upwelling west of Papagayo is strong year-round. This occurs because the shear remains strong in summer between the weak Papagayo jet and the southwesterlies to the south that converge toward the Central American land bridge. As a result, the strongest annual-mean upwelling over the entire eastern Pacific warm pool is found south of the Papagayo gap rather than over the Gulf of Tehuantepec. Kessler's (2002) calculations show that the observed thermocline topography is consistent with forcing by Ekman pumping according to linear Sverdrup dynamics. Indeed, the Ekman upwelling band southeast of the Papagayo jet axis forces a zonal band of shallow thermocline extending west along $6^{\circ}-12^{\circ} \mathrm{N}$ (Fig. 4a). At the center of this Costa Rica Dome, the $20^{\circ} \mathrm{C}$ isotherm is only $30 \mathrm{~m}$ deep. The $20^{\circ} \mathrm{C}$ isotherm tracks the tightly packed thermocline quite well in this region (Fig. 5). In the zonal direction, this thermocline dome is highly asymmetric. The thermocline shoals rapidly from the Central American coast to $90^{\circ} \mathrm{W}$ under the strong Ekman pumping associated with the Papagayo wind jet, and deepens slowly to the west where the Ekman pumping nearly vanishes. In the meridional direction, the $20^{\circ} \mathrm{C}$ isotherm is equally shallow at the Costa Rica Dome as in the equatorial upwelling zone.

The thermocline topography and Ekman pumping are related by the Sverdrup relation:

$$
h-h_{E}=-\frac{f^{2}}{g^{\prime} H \beta} \int_{x_{E}}^{x} w_{e} d x,
$$

where $h$ is the thermocline depth deviation from its mean value $H$, the subscript $E$ denotes values at the eastern boundary, $g^{\prime}$ is the reduced gravity, $\beta$ the meridional derivative of the Coriolis parameter, and $x$ is the longitudinal coordinate (positive eastward). Here we have used a 1.5-layer model [Kessler (2002) discusses the limitations of such a model for the eastern tropical Pacific]. For a zonally oriented band of Ekman upwelling like the one associated with the Papagayo jet, its effect accumulates in the zonal integral and produces a large response in the thermocline depth to the west (Fig. 4). This is the main mechanism for the generation of the Costa Rica Dome (Kessler 2002).

The orientation of a wind jet is very important for its effect on thermocline topography. In contrast to the zonally oriented Papagayo jet, consider a meridional wind jet that is symmetric about its axis (i.e., ignore the anticyclonic inertial turning). In this case, the zonal integral in Eq. (1) sums the contributions across both sides 

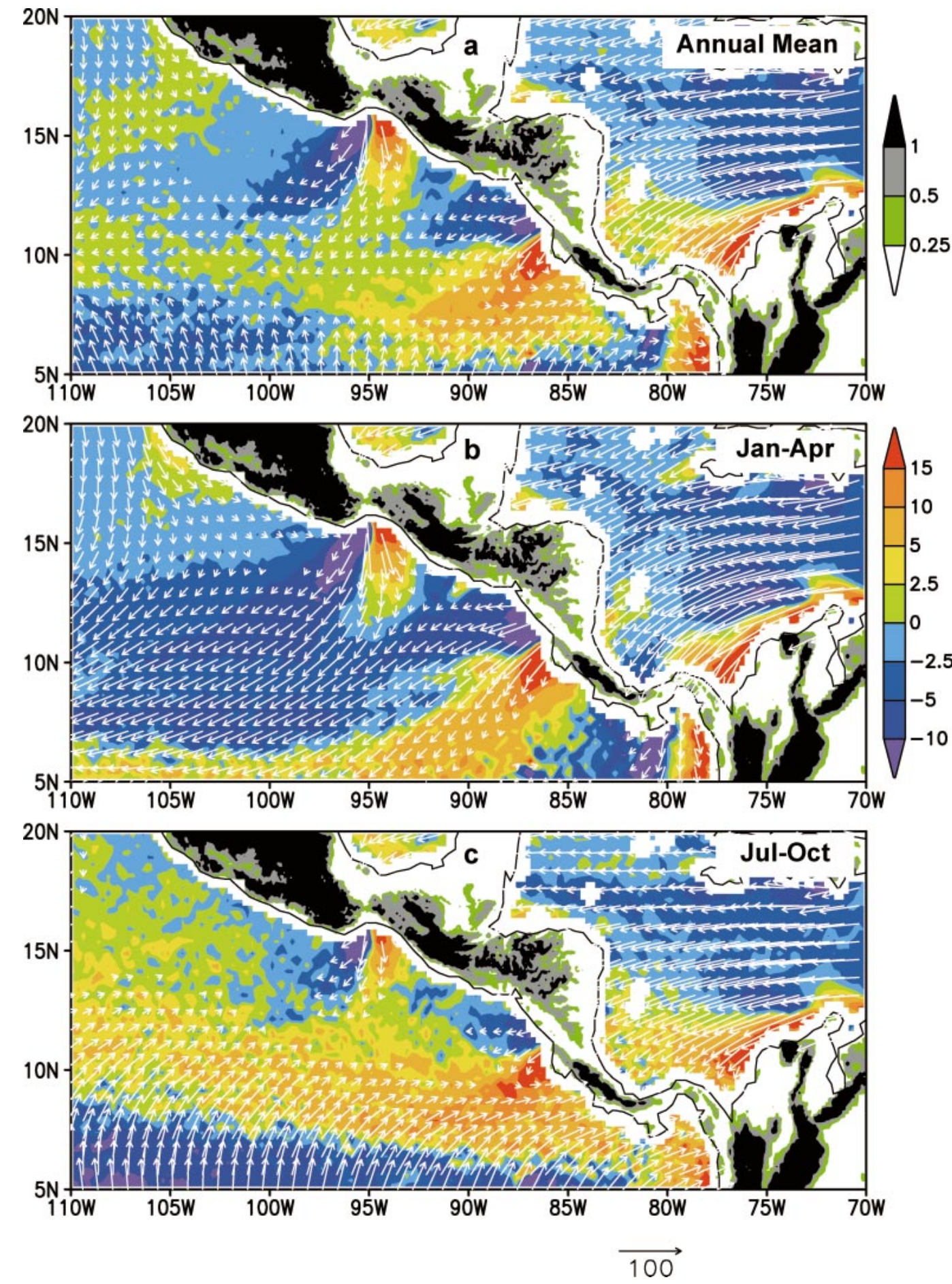

FIG. 3. QuikSCAT pseudo-wind stress (vectors in $\mathrm{m}^{2} \mathrm{~s}^{-2}$ ) and Ekman pumping velocity (shade in $10^{-6} \mathrm{~m} \mathrm{~s}^{-1}$ ) climatology: (a) annual mean, (b) Jan-Apr, and (c) Jul-Oct. Land orography (km) is plotted in color shading.

of the meridionally oriented wind-curl dipole, so its net effect on the thermocline cancels at longitudes sufficiently far from the wind jet. Physically, this represents the westward propagation of Rossby waves across forcing regions of opposite signs. Thus, the thermocline depth decrease produced by the Tehuantepec upwelling on the eastern flank of the jet is visible but highly localized, not fully developed in strength and spatial extent because of the opposing forcing by the negative vorticity on the western flank of the jet. A close in- 

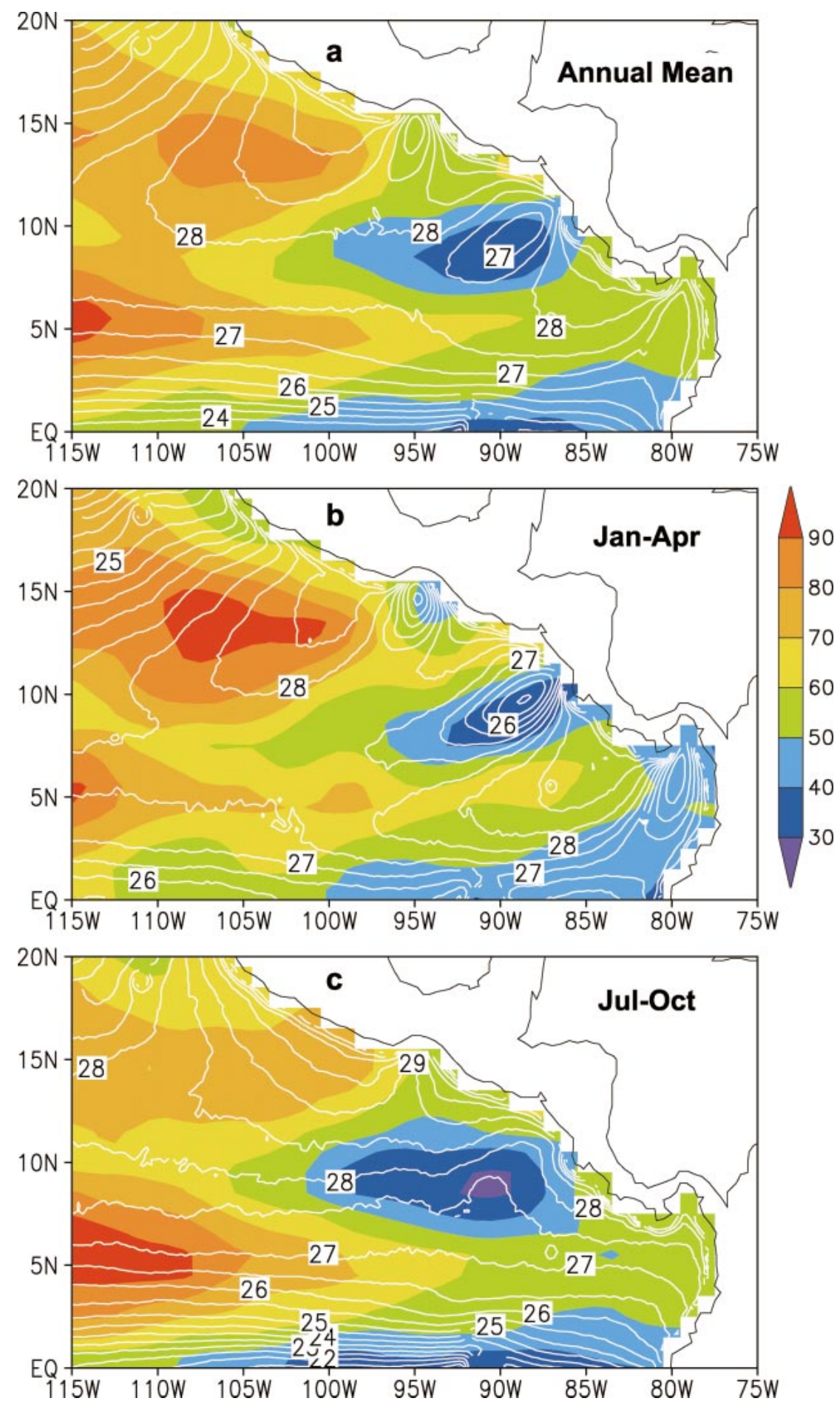

FIG. 4. Climatology of SST (contours at intervals of $0.5^{\circ} \mathrm{C}$ ) and the $20^{\circ} \mathrm{C}$ isotherm depth (color in m): (a) Annual mean, (b) Jan-Apr, and (c) Jul-Oct.

spection indicates that the Tehuantepec jet curl becomes asymmetric as it extends southward: the Ekman downwelling on the west becomes greater than the upwelling to the east (Figs. 3a,b), likely an effect of earth rotation on the jet (Clarke 1988; Steenburgh et al. 1998). This stronger downwelling of the Tehuantepec jet, helped by the downwelling of the background (especially in winter), forces a thermocline bowl centered at $13^{\circ} \mathrm{N}, 107^{\circ} \mathrm{W}$ (Fig. 4b; KES). It is unclear what determines the orientation of a wind jet, but the geometry of the mountain 

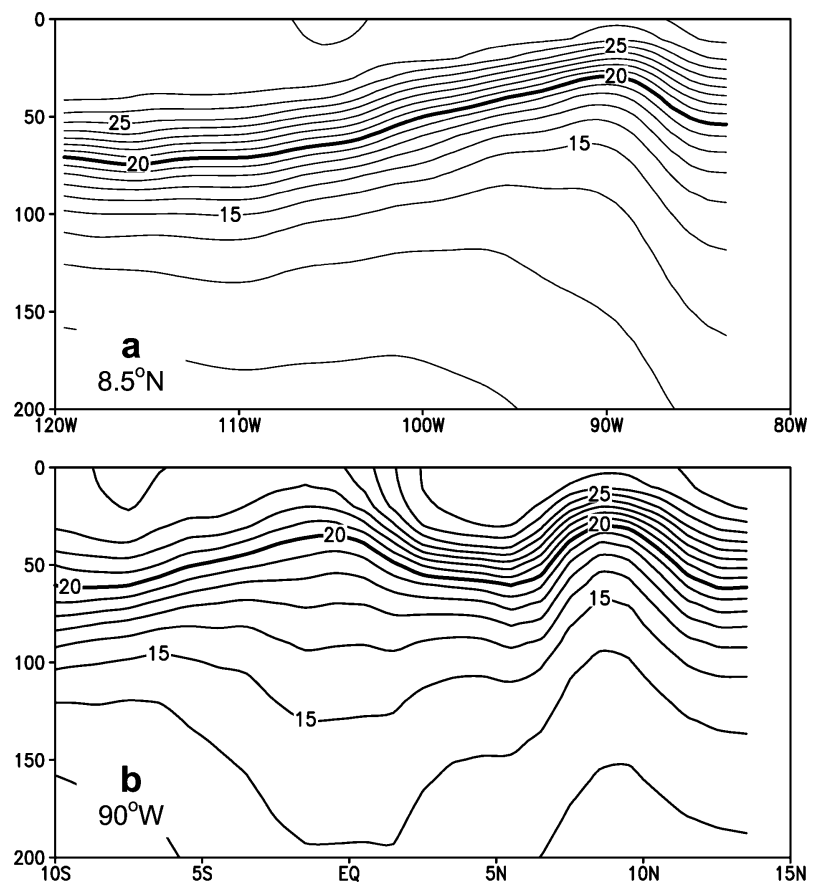

Fig. 5. Mean ocean temperature $\left({ }^{\circ} \mathrm{C}\right)$ along (a) $8.5^{\circ} \mathrm{N}$ and (b) $90^{\circ} \mathrm{W}$.

pass seems to be an important factor. While the pass north of Tehuantepec favors a northerly wind jet, the Papagayo pass allows winds to accelerate only in the zonal direction, leading to a strong thermocline response that extends well to the west.

\section{c. Effect on SST}

In winter, intense cooling induced by the wind jets leaves marked signatures on the SST field. Under each of these wind jets is a band of cold water with SST well below $27^{\circ} \mathrm{C}$ (Fig. 6a) due to increased surface heat flux and vertical mixing. This wind-induced decrease is so strong that the minimum SST is less than $25^{\circ} \mathrm{C}$ in this multiseason-average map, against background SSTs of $28^{\circ} \mathrm{C}$ or above in the warm pool. The SST minima are roughly aligned with the axes of wind jets, trailing the mountain passes over a long distance. The thermocline topography appears to also be an important factor for the SST decrease, and although a quantitative heat balance is beyond the scope of this paper, some conclusions about the importance of surface heat fluxes versus stirring from the shallow thermocline can be drawn. Note that the Papagayo cold patch is roughly collocated with the thermocline ridge and extends $1000 \mathrm{~km}$ offshore while the Tehuantepec cold patch extends only half as far because its upwelled thermocline is confined closer to the coast (Fig. 4b). Also, the coldest SST appears to be found slightly offshore (Fig. 4), as the thermocline shoals (Fig. 5a), not precisely under the strongest winds

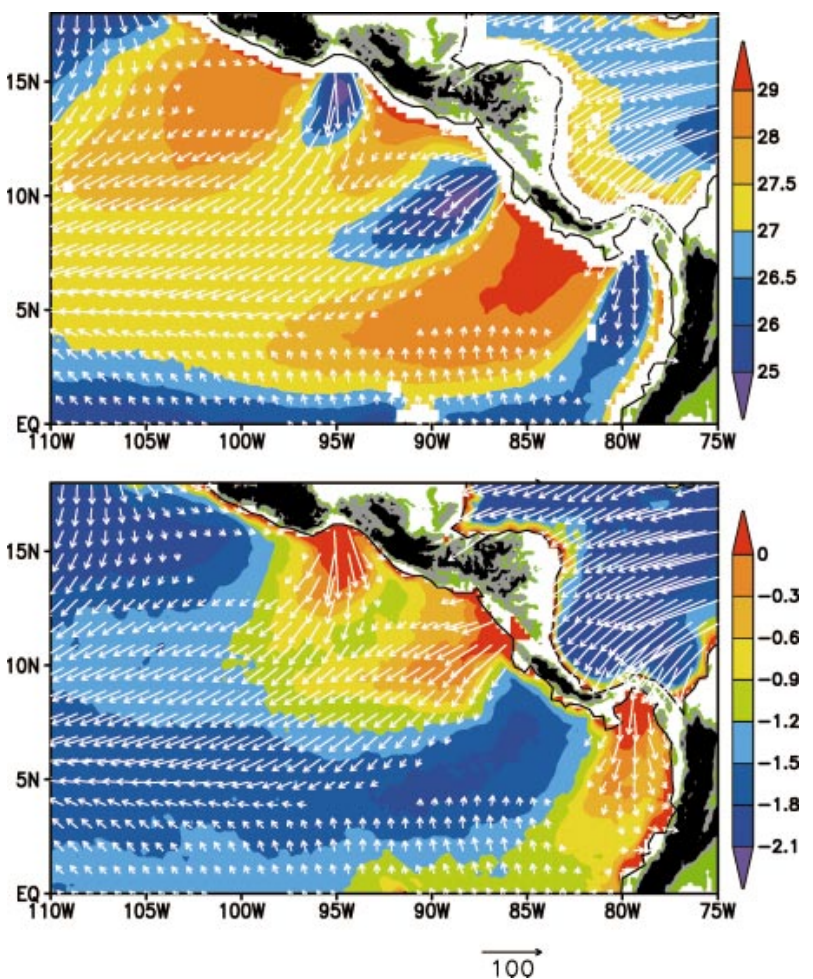

FIG. 6. Jan-Mar climatology: QuikSCAT pseudo-wind stress (vectors; $\mathrm{m}^{2} \mathrm{~s}^{-2}$ ): (top) TMI SST $\left({ }^{\circ} \mathrm{C}\right)$ and (bottom) SeaWiFS chlorophyll in natural logarithm $\left(\mathrm{mg} \mathrm{m}^{-3}\right)$.

at the coast. The strong entrainment made possible by strong winds and a shallow thermocline is further manifested in a tongue of high chlorophyll concentrations as observed by the SeaWiFS satellite over each of the Tehuantepec, Papagayo, and Panama jets (Fig. 6b). In winter, the shallow thermocline in the Costa Rica Dome and off the coast of South America, which is itself a response to the vorticity forcing by the Papagayo and Panama jets, aids the wind-induced cooling. The SST minimum and the thermocline depth minimum are roughly collocated over these two cold patches (Fig. 4b), allowing them to extend far offshore.

While the cold patches in the annual-mean SST map are dominated by the winter cooling, there are also significant features in summer SST. The summer SST distribution in the warm pool is very different from that in winter (Fig. 4). SST contours are zonally oriented south of $10^{\circ} \mathrm{N}$ and become somewhat parallel to the coast near Central America. A weak cold wedge develops offshore of the Gulfs of Tehuantepec and $\mathrm{Pa}$ pagayo. The cooling over the Gulf of Tehuantepec seems a weaker echo of its stronger counterpart in winter, but the cooling off Papagayo extends much farther offshore than the wind jet (Fig. 3c), suggesting the importance of the shallow thermocline and resulting entrainment, rather than the effect of surface heat flux, for the openocean cooling in summer. At and south of $10^{\circ} \mathrm{N}$, summer 


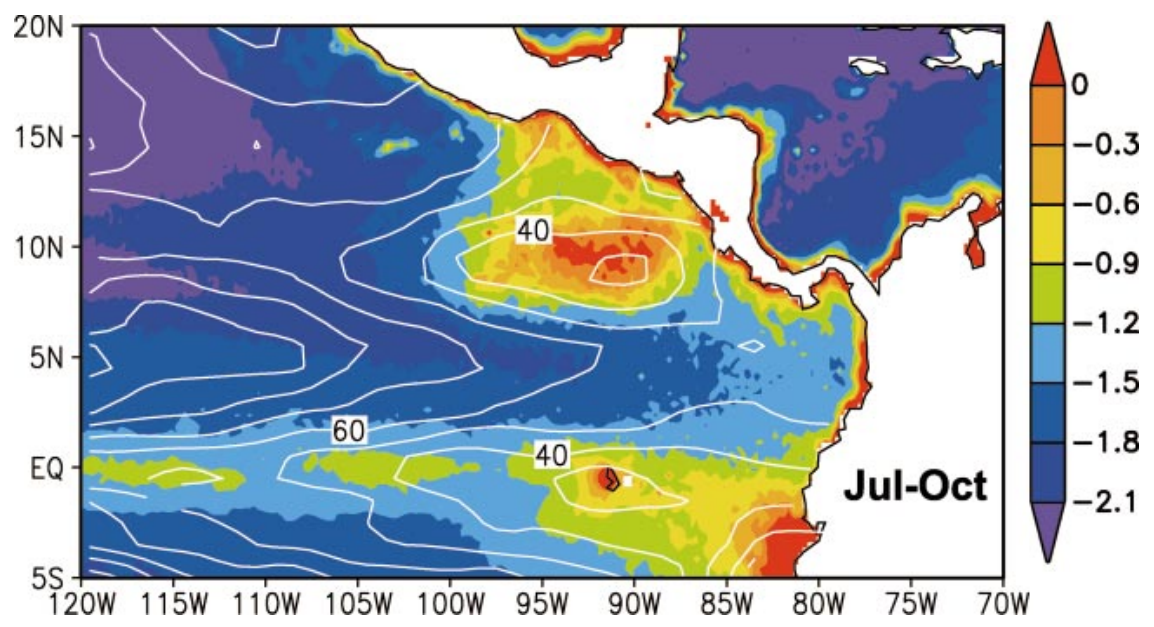

FIG. 7. SeaWiFS chlorophyll in natural logarithm (shade; $\mathrm{mg} \mathrm{m}^{-3}$ ) and $20^{\circ} \mathrm{C}$ isothermal depth (contours; m) climatology for Jul-Oct.

cooling is located at the peak of the Costa Rica Dome (Fig. 4c), where the ocean mixed layer is only about 10 $\mathrm{m}$ deep (Fig. 5) and the $20^{\circ} \mathrm{C}$ isotherm is shallower than $30 \mathrm{~m}$. The doming thermocline there allows cold water to be upwelled or easily entrained into the mixed layer. Further west, the thermocline deepens and summer SST can warm (Fig. 4c). However, high chlorophyll activity in summer is organized into a zonal patch centered at $9^{\circ} \mathrm{N}$ extending $10^{\circ}$ in longitude and $5^{\circ}$ in latitude, closely collocated within the $40-\mathrm{m}$ depth contour of the $20^{\circ} \mathrm{C}$ isotherm (Fig. 7). The difference between the patterns of SST and chlorophyll suggests that the high chlorophyll in the western Costa Rica Dome is due to biological activity below the surface mixed layer, which is shallow enough to receive sufficient sunlight for photosynthesis, but too deep to easily entrain cool water to the surface. In situ observations are necessary to test this hypothesis.

\section{d. SST feedback on atmosphere}

With the wind jets strongest and the SST features most sharply defined in winter (Fig. 6a), one might expect that their effects on atmospheric convection through the cold SST patches would also be strongest in winter. This is true for the Panama jet; the cold patch it induced suppresses atmospheric convection, giving rise to a band of local minimum in precipitation (Fig. $8 \mathrm{~b})$. However, the Tehuantepec and Papagayo jets and associated cold patches have little effect on winter precipitation because they are located in a dry region north of the ITCZ. West of about $110^{\circ} \mathrm{W}$, the winter ITCZ is roughly collocated with the high SST band, but further east it is kept south of $7^{\circ} \mathrm{N}$ and consistently displaced to the southern boundary of the eastern Pacific warm pool $^{1}$ (Fig. 8b).

In boreal summer, the ITCZ takes a more northerly position, occupying a large latitudinal band between $7^{\circ}$ and $15^{\circ} \mathrm{N}$ that includes the cold patch over the Costa Rica Dome (Fig. 8c). Within this broad ITCZ, there is a hole of precipitation deficit over the cold spot on top of the Costa Rica Dome. This hole in the ITCZ is over $500 \mathrm{~km}$ in diameter with a $50 \%$ drop in precipitation $\left(5 \mathrm{~mm} \mathrm{day}{ }^{-1}\right.$ in the hole versus $10 \mathrm{~mm}$ day $^{-1}$ for the background). Below the dry hole, SST reaches a minimum in the zonal direction, suggesting that the cold spot forces the rainfall deficit. If we assume that cloudiness is roughly proportional to precipitation in this region of deep convection, the increased solar radiation under the dry hole is a negative feedback that acts to dampen the cold spot in SST, further supporting the notion that the thermocline dome maintains both the cold spot and hole in the ITCZ.

The weak summer jet off Tehuantepec leaves small but visible signatures in both SST and chlorophyll, but apparently not in precipitation. Probably this is because the SST remains above $28.5^{\circ} \mathrm{C}$ under the weak summer jet (Fig. 8b). Neither the Tehuantepec nor Panama jets have much effect on the thermocline depth in summer. The Costa Rica Dome, by contrast, is strong year-round. This permanent thermocline dome is a result of upwelling curl associated in winter with the Papagayo jet,

\footnotetext{
${ }^{1}$ In winter, as the prevailing easterly trades impinge on the Central American mountains, orographic downdraft suppresses convection off the Pacific coast, displacing the ITCZ away from the bulk of the warm pool. Numerical experiments using the model described in the appendix indicate that this effect of the broad mountain range conceals the effect of shorter-scale gap winds on convection off Tehuantepec and Papagayo in winter (Xu et al. 2004b, manuscript submitted to J. Climate).
} 

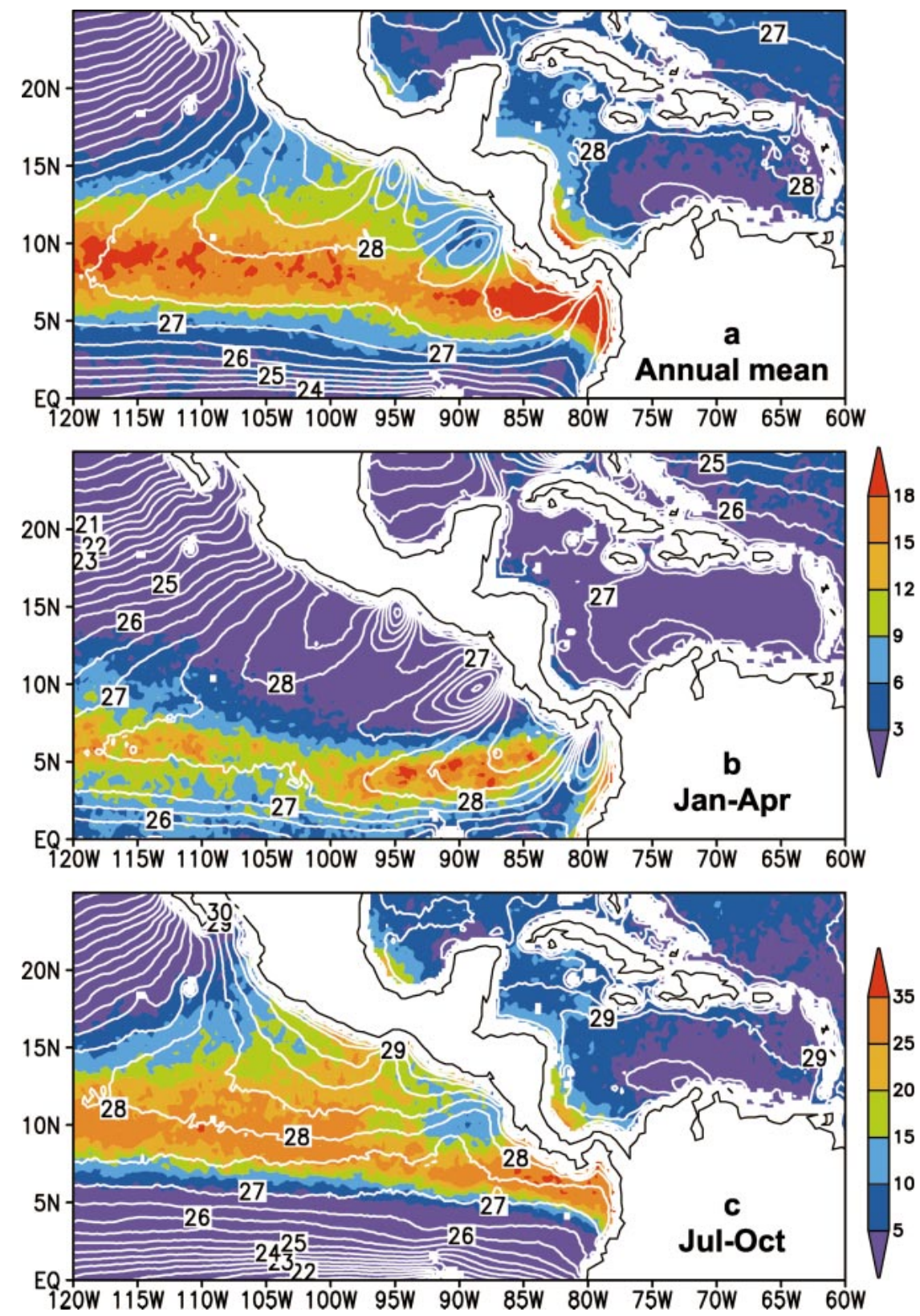

FIG. 8. TMI SST (contours; ${ }^{\circ} \mathrm{C}$ ) and precipitation (shade; $\mathrm{mm}^{\mathrm{Tay}}{ }^{-1}$ ) climatology: (a) annual mean, (b) Jan-Apr, and (c) Jul-Oct. In (c), note the different color scale for summer.

helped by its orientation that efficiently excites the thermocline response, and in summer, additionally by the positive curl of the ITCZ. As a result, SST over the Costa Rica Dome remains below $28.5^{\circ} \mathrm{C}$ throughout the seasonal cycle (Fig. 8), which inhibits atmospheric convection when the ITCZ moves overhead in summer. Although the winter Papagayo jet does not have a direct effect on winter atmospheric convection, its curl makes an important contribution to maintaining the robust thermocline dome that persists throughout the year. If not for the winter jet, the Ekman upwelling would be only a result of the ITCZ, and thus would be in phase with the precipitation, as it is west of $90^{\circ} \mathrm{W}$ (Figs. 12a,c); cool SST due to entrainment would lag precipitation by $90^{\circ}$ and have only a small, delayed effect. Thus, the cold spot and the collocated rainfall deficit in summer may be viewed as partly resulting from the winter forcing through the ocean memory in the form of the Costa Rica Dome.

In September, the climatological Papagayo jet disappears altogether, with winds directed onshore instead of offshore (Figs. 9a and 12a show that the onshore winds last only about 1 month). The curl, however, remains weakly positive (Fig. 12a). Thus the September 


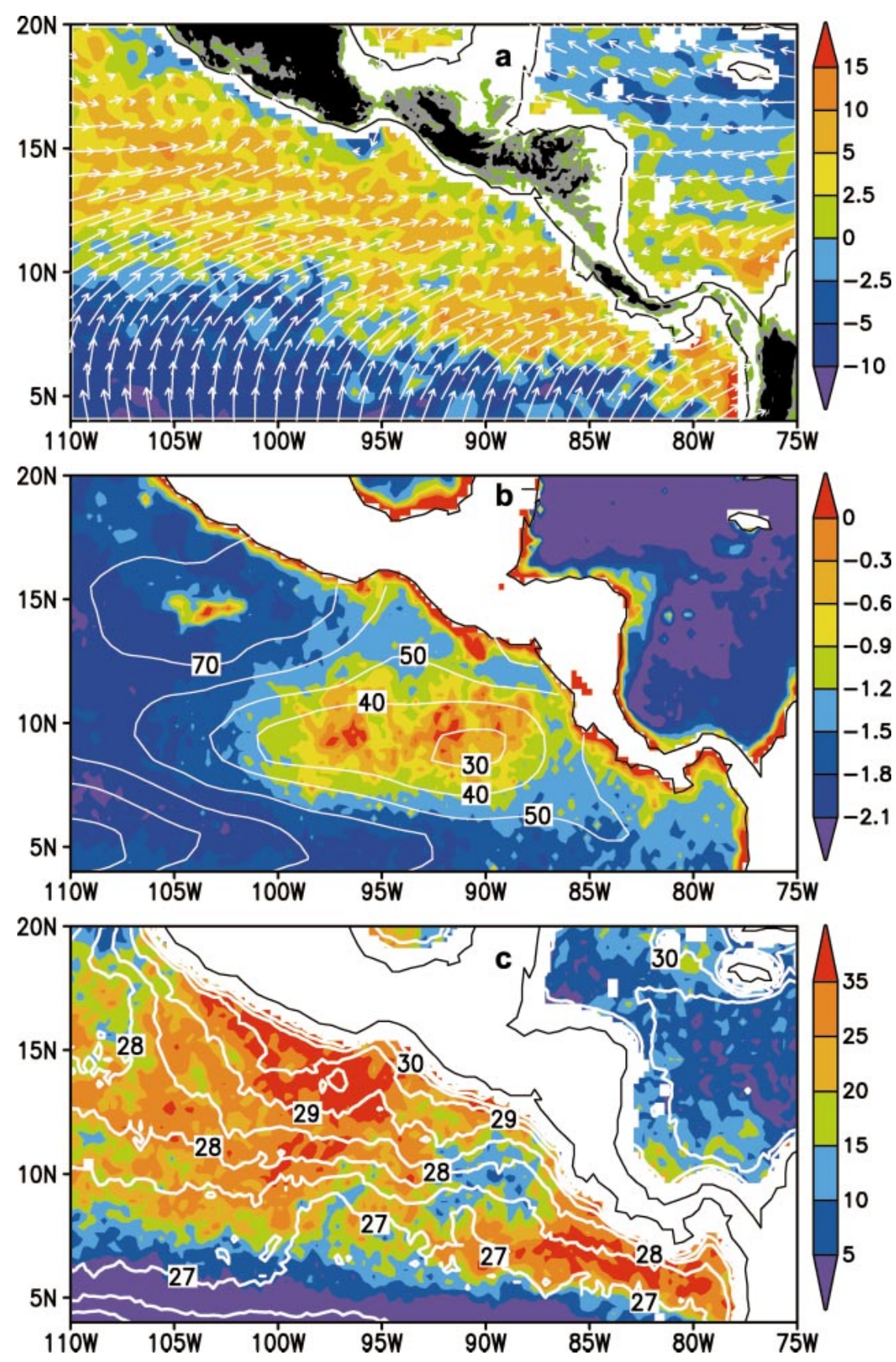

FIG. 9. Sep climatology: (a) QuikSCAT pseudo-wind stress (vectors; $\mathrm{m}^{2} \mathrm{~s}^{-2}$ ) and Ekman pumping velocity (color; $10^{-6} \mathrm{~m} \mathrm{~s}^{-1}$ ); (b) SeaWiFS chlorophyll in natural logarithm (color; $\mathrm{mg}$ $\mathrm{m}^{-3}$ ) and $20^{\circ} \mathrm{C}$ isothermal depth (contours; m); (c) TMI precipitation (color; mm day ${ }^{-1}$ ) and SST (contours; ${ }^{\circ} \mathrm{C}$ ).

climatology offers an example showing that the direct wind forcing of the weak summer Papagayo jet is not essential for the cold spot and resulting dry hole in the ITCZ. Thus, the effect appears to be the result of the persistent shallow thermocline of the Costa Rica Dome. Indeed, the cold SST spot around $90^{\circ} \mathrm{W}$ remains of the same strength as the summer mean and reaches all the way to the coast of Central America, causing a precipitation reduction in a $5^{\circ} \times 5^{\circ}$ area.

The dry hole in the summer ITCZ is not visible in the popular $2.5^{\circ} \times 2.5^{\circ} \mathrm{CMAP}$ rainfall product, probably because of insufficient resolution and spatial smoothing. Its existence is confirmed by higher-resolution datasets based on independent rainfall measure- 

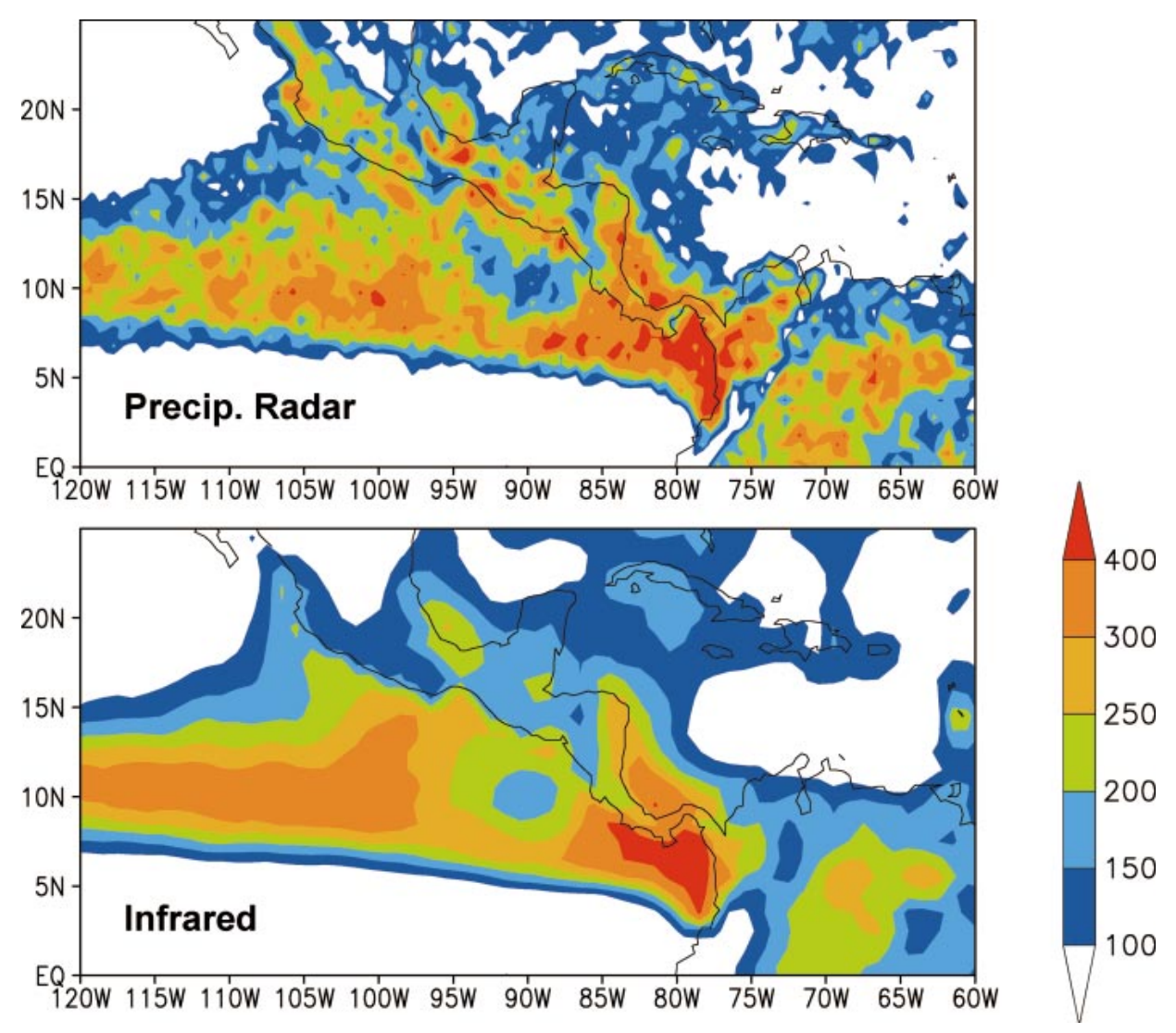

FIG. 10. Jul-Oct precipitation (mm month ${ }^{-1}$ ) based on the (top) TRMM PR (3A25G2) and (bottom) infrared (3B43) measurements.

ments by the TRMM PR and infrared (IR) instruments on the TRMM and geostationary satellites (Fig. 10). While noisy, the PR observations show increased rainfall on the coast, suggesting that direct orographic origin of this dry hole over the open ocean is unlikely. Degraded in spatial resolution but with excellent sampling, IR measurements reaffirm that this hole of rainfall deficit is found offshore roughly collocated with the Costa Rica

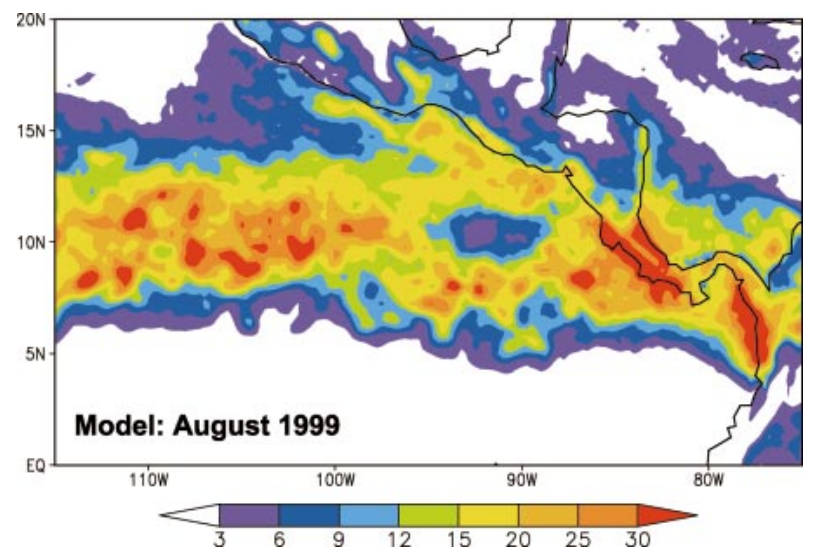

FIG. 11. Precipitation $\left(\mathrm{mm}\right.$ day $\left.^{-1}\right)$ in a regional atmospheric model, averaged for Aug 1999.
Dome. Rainfall maxima near the coast of Central and northwestern South America may be influenced by the diurnal land/sea breeze, in which orography plays a role (e.g., Mapes et al. 2003).

To test the effect of orography, we carried out a highresolution simulation with a regional atmospheric model briefly described in the appendix. Figure 11 shows the simulated rainfall for August 1999. While the simulated ITCZ is too thick in its meridional width west of $105^{\circ} \mathrm{W}$, the model captures the salient features of the observed summer rainfall pattern. In particular, pronounced rainfall deficits are found over the open ocean near the Costa Rica Dome. This hole of rainfall deficit remains in an additional experiment in which the land orography on Central American is removed and set uniformly at 0.5 $\mathrm{m}$ above the sea level. Thus, the dry hole in the ITCZ must be due to the cold spot maintained by the persistent shallow thermocline of the Costa Rica Dome.

The ITCZ is twice as strong in summer as in winter in terms of precipitation over the eastern Pacific (note the difference in color scale between Figs. 8a,b and 8c). As a result, the annual-mean rainfall distribution bears a strong resemblance to the summer distribution (Fig. $8 \mathrm{a}$ ). The annual-mean ITCZ is broad west of $95^{\circ} \mathrm{W}$, occupying a latitudinal band of $5^{\circ}-13^{\circ} \mathrm{N}$. East of $95^{\circ} \mathrm{W}$, it 
(a) Ekman pumping

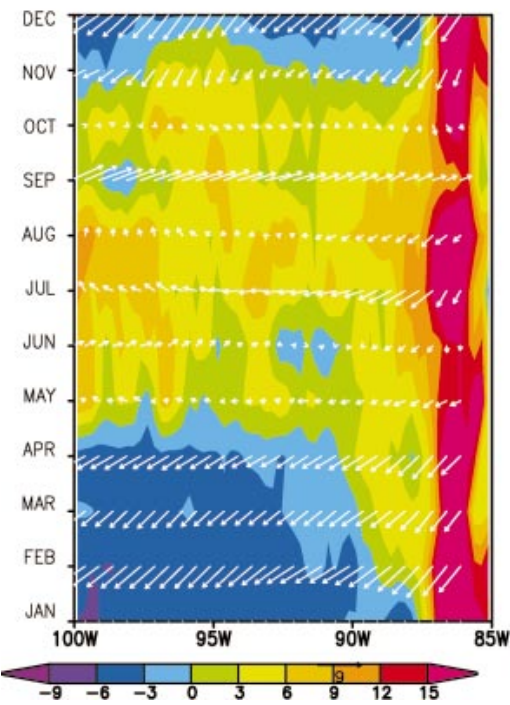

(b) Chlorophyll \& SSH

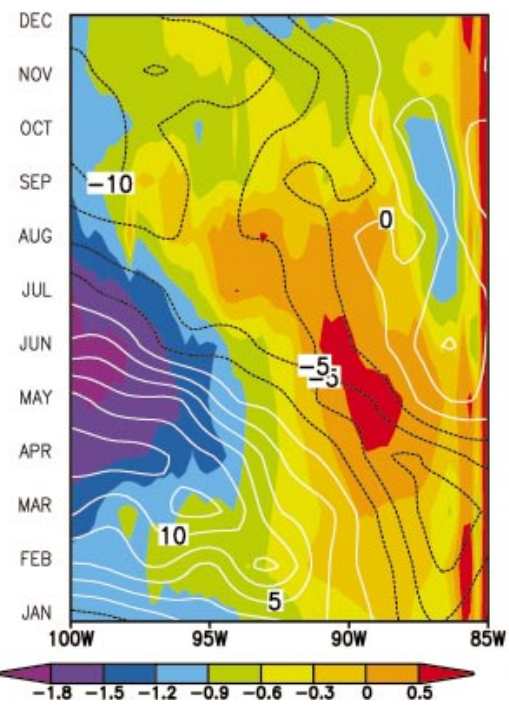

(c) Precip \& SST

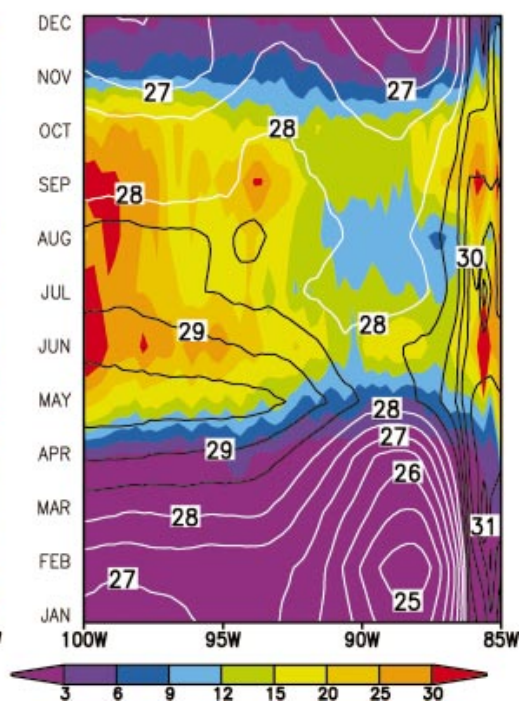

FIG. 12. Longitude-time sections averaged between $9^{\circ}$ and $11^{\circ} \mathrm{N}$ : (a) wind velocity $\left(\mathrm{m} \mathrm{s}^{-1}\right.$ ) and Ekman pumping velocity (shade; $10^{-6} \mathrm{~m}$ $\mathrm{s}^{-1}$ ); (b) chlorophyll in natural logarithm (color; $\mathrm{mg} \mathrm{m}^{-3}$ ) and merged sea level height (contours; cm); (c) TMI precipitation (shade; mm day $^{-1}$ ) and SST (contours; ${ }^{\circ} \mathrm{C}$ ).

narrows with the axis trending south into the Gulf of Panama (Fig. 8a). The summer Costa Rica Dome effect leaves a clear mark in the annual-mean field that appears as a region of minimum rainfall off Papagayo. In contrast to the strong summer effect on annual-mean rainfall, the annual-mean SST resembles the winter field featuring all three cool patches off Tehuantepec, Papagayo, and Panama. This difference in seasonal weight between SST and precipitation illustrates the importance of analysis at seasonal or finer resolution in time-on the annual mean map. (Fig. 8a), cold patches do not always lead to suppressed convection over the eastern Pacific warm pool.

\section{e. Seasonal cycle}

Having discussed seasonal-mean climate in summer and winter, we now describe the full seasonal cycle along $10^{\circ} \mathrm{N}$ (Fig. 12), a latitude that cuts through the Costa Rica Dome. SSH and thermocline depth are related by SSH $=g^{\prime} h / g$ in a 1.5-layer model ( $g$ is the gravity at the earth's surface), and we will use terms of $\mathrm{SSH}$ and thermocline depth interchangeably here. We use SSH to describe thermocline depth variations because it is better sampled with satellite observations. The $20^{\circ} \mathrm{C}$ isotherm shows a similar seasonal cycle, albeit smoother in space and time (not shown).

The positive curls off Papagayo are strong nearly year-round and are responsible for the permanent thermocline dome to the west. The gap winds vanish in September and October (Fig. 12a) when the Atlantic ITCZ takes its northernmost position, relaxing the pressure gradient across Central America. The seasonal cycle in thermocline depth behaves differently east and west of $90^{\circ} \mathrm{W}$, which is where $\mathrm{SSH}$ variance is at its zonal minimum. East of $90^{\circ} \mathrm{W}$, the strong wind jet and its curl force the thermocline to shoal in winter; then the near-shore thermocline deepens in summer as the gap winds weaken. Wind curls display a seasonal cycle of an opposite phase west of $90^{\circ} \mathrm{W}$, negative in winter when the ITCZ is to the south and positive in summer when the ITCZ is overhead. The latent heat release by ITCZ convection generates positive vorticity in the lower troposphere, which in turn forces an Ekman suction that lifts the thermocline. While the Ekman pumping variation is more or less stationary in space, the thermocline response displays a clear westward propagation indicative of Rossby waves (Fig. 12b). West of $90^{\circ} \mathrm{W}$, the thermocline deepens during the first half of the year and shoals during the second half. Because of the opposite phasing in Ekman pumping variations to its east and west, the center of the Costa Rica Dome at $90^{\circ} \mathrm{W}$ experiences little seasonal variations. A 1.5-layer linear reduced-gravity model simulates this observed annual cycle in SSH rather well (not shown), suggesting that these simple wave dynamics dominate the seasonal time scale (KES).

In winter, the cold patch induced directly by the strong Papagayo jet cuts through $10^{\circ} \mathrm{N}$ at $88^{\circ} \mathrm{W}$. This cold patch starts to develop in October, reaches a maximum in February, and persists through April (Fig. 12c). In May, the summer regime begins to take over, with SST reaching its seasonal maximum and the ITCZ covering this latitude, but SST over the dome is still cooler than either to the east or west (Fig. 12c). During the summer, there is a weak but persistent minimum in SST around $90^{\circ} \mathrm{W}$, the center of the Costa Rica Dome. A region of reduced 
rainfall is roughly collocated with the region of SST minimum during May-October. The rainfall deficit over the Costa Rica Dome is especially large in July and August, with values less than half of that at $100^{\circ} \mathrm{W}$. Over the dome, precipitation reaches a local minimum in time during July-August, suggesting that the shoaling thermocline and its cooling effect may play a role in creating the midsummer drought reported in Magana et al. (1999).

The seasonal variations in chlorophyll are quite complicated but generally follow the thermocline depth variations with a lag of 0-2 months (Fig. 12b). At the center of the Costa Rica Dome $\left(90^{\circ} \mathrm{W}\right) \mathrm{SeaWiFS}$ chlorophyll reaches a seasonal maximum in May when SSH reaches a minimum. Further to the west, chlorophyll reaches a seasonal minimum during May-June 2 months after the SSH maximum. SSH's control over chlorophyll variations is further corroborated by their westward copropagation. The seasonal cycle of chlorophyll seems to be induced not by the local Ekman pumping-the two are roughly in quadrature in phase west of $95^{\circ} \mathrm{W}$. Instead, the chlorophyll cycle is consistent with an equilibrium response to thermocline depth.

\section{Summary}

We have used a suite of new satellite observations to study air-sea interaction over the eastern Pacific warm pool. The use of these satellite observations allows us to map the covarying ocean-atmospheric structure in detail not possible before. Our analysis confirms the existence of strong atmospheric dynamic and thermodynamic forcing of the ocean in winter and also reveals that patterns of SST induced by ocean dynamics force the atmosphere on short spatial scales in boreal summer. In winter as the pressure difference between the tropical northwestern Atlantic and northeastern Pacific builds up, the mountains of Central America funnel strong winds through three major passes: Tehuantepec, Papagayo, and Panama. The Papagayo pass, in particular, directs a westward wind jet over the Pacific. The positive wind stress curl south of this wind jet is strongest in winter but exists almost year-round, forcing a thermocline dome centered about $200 \mathrm{~km}$ offshore (the Costa Rica Dome). The thermocline depth at the center of this dome is shallow all year, with an ocean mixed layer only about $10 \mathrm{~m}$ deep. This thermocline dome allows cold water to be easily mixed into the mixed layer, giving rise to a cold spot in summer SST and a collocated patch of high chlorophyll activity. This surface cooling at the top of the Costa Rica Dome suppresses atmospheric convection, opening a large hole of reduced rainfall in the ITCZ southwest of Papagayo.

The Tehuantepec, Papagayo, and Panama wind jets and their cooling effect on the winter SST are a wellknown phenomenon. Although all three jets have pronounced $\left(3^{\circ} \mathrm{C}\right)$ effects on winter SST, we have shown that the effect on precipitation is different among the three jets, depending on their latitude with respect to the ITCZ and its annual march, the orientation of the jets, and their correlation with upwelling curl in the ITCZ itself. The Panama jet produces a gap in the winter ITCZ, which is at its southernmost position when the jet is strong. The Tehuantepec jet has little effect on ITCZ precipitation at any time of year because it is far to the north of the ITCZ when the jet is strong in winter, and its summer SST signature is small. The Papagayo jet makes a hole in the ITCZ in summer, because persistent upwelling curl, combined with Rossby wave radiation from the strong zonally oriented winter jet, shoals the thermocline throughout the year and maintains cool SST even in summer.

Thermocline domes are observed in other parts of the World Ocean, and their importance for marine biology is well known because of their supply of nutrients. The climatic effect of these domes has just begun to be recognized. Over these domes, cool thermocline water can easily come into contact with the sea surface either by Ekman pumping or by turbulent mixing. As a result, the thermocline depth and its variations exert a strong influence in SST above the domes. In the South Indian Ocean dome, for example, interannual Rossby waves modulate the thermocline dome at $5^{\circ}-10^{\circ} \mathrm{S}$, producing strong variations in SST, atmospheric convection, and tropical cyclones (Xie et al. 2002; Yamagata et al. 2004; Annamalai and Murtugudde 2004). The present study of the Costa Rica Dome provides another example of enhanced air-sea interaction over thermocline domes. The eastern Pacific warm pool is also an important region for cyclogenesis (e.g., Maloney and Hartmann 2000), so the surface cooling due to the Costa Rica Dome may influence the formation or pathways of eastern Pacific hurricanes, an effect that would be worth further study using regional atmospheric models.

Mountains perturb airflow and commonly leave distinct marks on surface winds over coastal waters or near islands (Chelton et al. 2004). If mountains are configured so that orographical-induced wind-curl patches are nearly zonally oriented, ocean Rossby waves are optimally excited. Because the ocean adjustment is slow and subject to weak dissipation, orographical-triggered air-sea interaction may have long-lasting effects in both the ocean and atmosphere. The Costa Rica Dome and its effect on summer convection revealed in this study, and the long wake of the Hawaiian Islands in various ocean-atmospheric fields (Xie et al. 2001) are such examples. The full extent of orographical-triggered airsea interaction has just begun to be unraveled by satellite observations which have brought unprecedented spatial resolution and temporal coverage. With increasing computing power, global models will eventually reach sufficient resolutions to resolve orographic features such as the mountain ranges of Hawaii and Central America. When they do, orographic-induced air-sea coupled phenomena documented here and elsewhere will serve as a benchmark for these models to reproduce. Toward this 
direction, a high-resolution coupled ocean-atmosphere model run on Japan's Earth Simulator is producing encouraging results showing signs of the ocean-atmosphere wake of Hawaii (Sakamoto et al. 2004) and the Costa Rica Dome.

Acknowledgments. This study was initiated during the first author's visit to Hokkaido University, Japan. He wishes to thank Y. Tanimoto, H. Tokinaga, faculty and students at Division of Ocean and Atmospheric Science for their hospitality, and J. Hafner for data processing. TMI and QuikSCAT products are obtained from Remote Sensing Systems, chlorophyll from Goddard DAAC, TRMM 3A25G2 and 3B43 products from EORC/JAXA, Japan, and SSH from the Collecte Localisation Satellites, France. Supported by NASA, NOAA, NSF, Japan Society for the Promotion of Science, and Japan Agency for Marine-Earth Science and Technology.

\section{APPENDIX}

\section{Atmospheric Model}

A regional atmospheric model developed at the International Pacific Research Center of the University of Hawaii is used. It is a primitive equation model solved on a longitude-latitude grid with sigma as the vertical coordinate. Its comprehensive physical package includes an $E-\varepsilon$ closure scheme for turbulence, cloud microphysics for grid-scale clouds and precipitation, a mass-flux cumulus parameterization for subgrid-scale convection, a cloud-interactive radiation scheme, and a land surface model. See Wang et al. (2004) and Xu et al. (2004a) for a detailed description of the model and its performance over the eastern Pacific.

Here the model resolution is set at $0.25^{\circ}$ in the horizontal and 28 levels in the vertical. The initial and lateral boundary conditions are constructed based on the National Centers for Environmental Prediction-National Center for Atmospheric Research (NCEP-NCAR) reanalysis dataset (Kalnay et al. 1996). The lateral boundary conditions are updated 4 times daily. The surface boundary conditions are the weekly $1^{\circ} \times 1^{\circ}$ Reynolds and Smith (1994) SST product. The model domain covers a region of $10^{\circ} \mathrm{S}-27.5^{\circ} \mathrm{N}, 125^{\circ}-75^{\circ} \mathrm{W}$. Land topography is based on the United States Geological Survey (USGS) earth topography ETOPO dataset. The model is initialized on 25 June 1999 and integrated for 3 months.

\section{REFERENCES}

Annamalai, H., and R. Murtugudde, 2004: Role of the Indian Ocean in regional climate variability. Ocean-Atmosphere Interaction and Climate Variability, Geophys. Monogr., No. 147, Amer. Geophys. Union, 213-246.

Barton, W. D., and Coauthors, 1993: Supersquirt: Dynamics of the Gulf of Tehuantepec, Mexico. Oceanography, 6, 23-30.

Chelton, D. B., M. H. Freilich, and S. N. Esbensen, 2000: Satellite observations of the wind jets off the Pacific coast of Central
America. Part I: Case studies and statistical characteristics. Mon. Wea. Rev., 128, 1993-2018.

_, M. G. Schlax, M. H. Freilich, and R. F. Milliff, 2004: Satellite measurements reveal persistent small-scale features in ocean winds. Science, 303, 978-983.

Chiang, J. C. H., Y. Kushnir, and S. E. Zebiak, 2000: Interdecadal changes in eastern Pacific ITCZ variability and its influence on the Atlantic ITCZ. Geophys. Res. Lett., 27, 3687-3690.

Clarke, A. J., 1988: Inertial wind path and sea surface temperature patterns near the Gulf of Tehuantepec and the Gulf of Papagayo. J. Geophys. Res., 93, 15 491-15 501.

Ducet, N., P. Y. Le Traon, and G. Reverdin, 2000: Global high-resolution mapping of ocean circulation from TOPEX/Poseidon and ERS-1 and -2. J. Geophys. Res., 105, 19 477-19 498.

Fiedler, P. C., 2002: The annual cycle and biological effects of the Costa Rica Dome. Deep-Sea Res., 49A, 321-338.

Hofmann, E. E., A. J. Busalacchi, and J. J. O'Brien, 1981: Wind generation of the Costa Rica Dome. Science, 214, 552-554.

Kalnay, E., and Coauthors, 1996: The NCEP/NCAR 40-Year Reanalysis Project. Bull. Amer. Meteor. Soc., 77, 437-471.

Kessler, W. S., 2002: Mean three-dimensional circulation in the northeast tropical Pacific. J. Phys. Oceanogr., 32, 2457-2471.

_- 2004: The circulation of the eastern tropical Pacific: A review. Progress in Oceanography, Pergamon, in press.

Legeckis, R., 1988: Upwelling off the Gulfs of Panama and Papagayo in the tropical Pacific during March 1985. J. Geophys. Res., 93, $15485-15489$.

Liu, W. T., X. Xie, P. S. Polito, S.-P. Xie, and H. Hashizume, 2000: Atmospheric manifestation of tropical instability waves observed by QuikSCAT and Tropical Rainfall Measuring Mission. Geophys. Res. Lett., 27, 2545-2548.

Magana, V., J. A. Amador, and S. Medina, 1999: The midsummer drought over Mexico and Central America. J. Climate, 12, 15771588.

Maloney, E. D., and D. L. Hartmann, 2000: Modulation of eastern North Pacific hurricanes by the Madden-Julian oscillation. $J$. Climate, 13, 1451-1460.

Mapes, B. E., T. T. Warner, and M. Xu, 2003: Diurnal patterns of rainfall in northwestern South America. Part I: Background and context. Mon. Wea. Rev., 131, 799-812.

McCreary, J. P., H. S. Lee, and D. B. Enfield, 1989: Response of the coastal ocean to strong offshore winds: With application to circulations in the Gulf of Tehuantepec and Papagayo. J. Mar. Res., 47, 81-109.

- . P. Lu, and Z. Yu, 2002: Dynamics of the Pacific subsurface countercurrents. J. Phys. Oceanogr., 32, 2379-2404.

Mitchell, T. P., and J. M. Wallace, 1992: The annual cycle in equatorial convection and sea surface temperature. J. Climate, 5, 11401156.

Reynolds, R. W., and T. M. Smith, 1994: Improved global sea surface temperature analyses using optimal interpolation. J. Climate, 7, 929-948.

Sakamoto, T., A. Sumi, S. Emori, T. Nishimura, H. Hasumi, T. Suzuki, and M. Kimoto, 2004: Far-reaching effects of the Hawaiian Islands in the CCSR/NIES/FRCGC high-resolution climate model. Geophys. Res. Lett., 31, L17212, doi:10.1029/2004GL020907.

Schultz, D. M., W. E. Bracken, L. F. Bosart, G. J. Hakim, M. A. Bedrick, M. J. Dickinson, and K. R. Tyle, 1997: The 1993 Superstorm cold surge: Frontal structure, gap flow, and tropical impact. Mon. Wea. Rev., 125, 5-39.

Steenburgh, W. J., D. M. Schultz, and B. A. Colle, 1998: The structure and evolution of gap outflow over the Gulf of Tehuantepec, Mexico. Mon. Wea. Rev., 126, 2673-2691.

Umatani, S., and T. Yamagata, 1991: Response of the eastern tropical Pacific to meridional migration of the ITCZ: The generation of the Costa Rica Dome. J. Phys. Oceanogr., 21, 346-363.

Wang, C., and D. B. Enfield, 2003: A further study of the tropical Western Hemisphere warm pool. J. Climate, 16, 1476-1493.

Wang, Y., S.-P. Xie, H. Xu, and B. Wang, 2004: Regional model simulations of marine boundary layer clouds over the Southeast 
Pacific off South America. Part I: Control experiment. Mon. Wea. Rev., 132, 274-296.

Wentz, F. J., C. Gentemann, D. Smith, and D. Chelton, 2000: Satellite measurements of sea surface temperature through clouds. Science, 288, 847-850.

Xie, P., and P. A. Arkin, 1996: Analyses of global monthly precipitation using gauge observations, satellite estimates, and numerical model predictions. J. Climate, 9, 840-858.

Xie, S.-P., 2004a: The shape of continents, air-sea interaction, and the rising branch of the Hadley circulation. The Hadley Circulation: Past, Present and Future, H. F. Diaz and R. S. Bradley, Eds., Springer-Kluwer Academic, in press.

2004b: Satellite observations of cool ocean-atmosphere interaction. Bull. Amer. Meteor. Soc., 85, 195-208.
,W. T. Liu, Q. Liu, and M. Nonaka, 2001: Far-reaching effects of the Hawaiian Islands on the Pacific Ocean-atmosphere. Science, 292, 2057-2060.

—, H. Annamalai, F. A. Schott, and J. P. McCreary Jr., 2002: Structure and mechanisms of South Indian Ocean climate variability. J. Climate, 15, 864-878.

Xu, H., Y. Wang, and S.-P. Xie, 2004a: Effects of the Andes on eastern Pacific climate: A regional atmospheric model study. J. Climate, $17,589-602$

Yamagata, T., S. K. Behera, J. J. Luo, S. Masson, M. R. Jury, and S. A. Rao, 2004: Coupled ocean-atmosphere variability in the tropical Indian Ocean. Ocean-Atmosphere Interaction and Climate Variability, Geophys. Monogr., No. 147, Amer. Geophys. Union, 189-212. 